\title{
Qualitative and Quantitative Determination of Phytochemicals In Aqueous Extract of Chrysophyllumalbidum Seed Kernel
}

\author{
Shamsu Adnan Muhammad ${ }^{1}$ and S.M. Abubakar ${ }^{2}$ \\ ${ }^{1}$ Department of Biotechnology, SRM University, Kattankulathur, Chennai, India. \\ ${ }^{2}$ Department of Biochemistry,Bayero University, Kano, Nigeria. \\ http://dx.doi.org/10.13005/bbra/2153
}

(Received: 15 March 2016; accepted: 12 May 2016)

\begin{abstract}
The phytochemicals in aqueous extract of Chrysophyllumalbidum seeds kernel were determined qualitatively and quantitatively in this study with a view to assess the potentials of this kernels as food and medicine. Results of this research showed that the seed kernel extracts contained alkaloids, flavonoids, tannins, cardiac glycosides and saponins. Quantitatively, C.albidum seed kernelwas found to contain alkaloids (3.56g/ $100 \mathrm{~g})$,tannins $(2.184 \mathrm{~g} / \mathbf{1 0 0 g})$, cardiac glycosides $(1.88 \mathrm{~g} / \mathbf{1 0 0 g})$, saponins $(0.24 \mathrm{~g} / \mathbf{1 0 0 g})$ and flavonoids $(0.15 \mathrm{~g} / 100 \mathrm{~g})$. Thepresences of these phytochemicals suggest the potentials of the kernel of C.albidum for use as a neutraceutical.
\end{abstract}

Keywords: Chrysophyllumalbidum, alkaloids, flavonoids, tannins, cardiac glycosides, saponins, terpenes, steroids, anthraquinones.

Plants that possess therapeutic properties or exert beneficial pharmacological effects on the animal body are generally designated as "medicinal plant"1. It's now been established that the plants which naturally synthesize and accumulate some secondary metabolites, like alkaloids, tannins, glycosides, volatiles oil and contain minerals and vitamins, possess medicinal properties $^{1}$.

Medicinal plants constitute an important natural wealth of a country. They play a significant role in providing primary health care services to rural people. They serve as therapeutic agents as well as important raw materials for the manufacture of traditional and modern medicines. Substantial amount of foreign exchange can be earned by

\footnotetext{
* To whom all correspondence should be addressed. E-mail;samgwarzo0113@gmail.com
}

exporting medicinal plants to other country. In this way indigenous medicinal plants play a significant role in the economy of a country ${ }^{2}$.

The practice of traditional medicine is worldwide custom and has preoccupied mankind in most civilized country ${ }^{2}$. In Nigeria, both herbal traditional and orthodox medicines are practiced, through the conventionally trained medical doctors are contemplating the former. Despite the fact that traditional approach to health care delivery system is popularly practiced and in spite of the availability of medicinal herbs in our local market, there are very few if any, in government health centers. This could be due to lack of adequate information on the composition, processing, dosage and crude of the medicinal plant preparation ${ }^{1}$.

The Chrysophyllumalbidum G.DonHoll (sapotaceae) tree is common throughout the tropical central, east and West African regions for its sweet edible fruits and various ethnomedicinal uses $^{3,4}$.Chrysophyllumalbidum fruits (known as 
African star apples) are widely consumed in southern Nigeria. The fruit is seasonal (DecemberMarch), ovoid to sub-globose, pointed at the apex, is orange to golden yellow when ripe and the pulp within the peel may be orange, pinkish, or light yellow. The pulp contains three to five seeds which are not usually eaten ${ }^{1}$. The seeds-coats are hard, bony, shiny, and dark brown, and when broken reveal white-coloured cotyledons. The fleshy fruit pulp is suitable for jams and is eaten especially as snack by both young and old ${ }^{4,5}$.The fruit has been found to have the highest content of ascorbic acid per $100 \mathrm{~g}$ of edible fruit or about 100 times that of oranges and 10 times of that of guava or cashew [6]. It is reported as an excellent source of vitamins, irons, flavours to diets ${ }^{7,8}$.

In addition, its seeds are a source of oil, which is used for diverse purposes. The fruits also contain $90 \%$ anacardic acid, which is used industrially in protecting wood and as a source of resin, while several other components of the tree including the roots and leaves are used for medicinal purposes ${ }^{9}$. The bark is used as a remedy for yellow fever and malaria, while the leaves are used as emollients and for the treatment of skin eruptions, diarrhea and stomach-ache, which are as a result of infections and inflammatory reactions ${ }^{9}$.

It is rich sources of natural antioxidant and have been established to promote health by acting against oxidative stress related disease such infections as; diabetics, cancer and coronary heart diseases ${ }^{10}$.

Recently studies have shown a diminished risk of chronic diseases in populations consuming diets high in fruits vegetables and it has been suggested that antioxidants found in large quantities in fruits and vegetables may be responsible for this protective effect ${ }^{11}$.Generally, foods antioxidant acts as reducing agents, reversing oxidation by donating electrons and hydrogen ions. Much attention has been focused on natural antioxidants and some antioxidants isolated from natural sources with high activity have been reported ${ }^{12}$.

\section{MATERIALSANDMETHODS}

\section{Sample Collection}

The Chrysophyllumalbidum seed kernel were obtained from the Rimi Market Kano and identified at the department of biological science Bayero University Kano, Nigeria. The pericarp and mesocarp region of the Chrysophyllumalbidum fruit were isolated from the endocarp region (seed) and then dried for weeks.

\section{Preparation and extraction of the aqueous extracts of $C$. albidum seeds kernel}

The outer shells of the seeds were cracked, open and the inner soft parts removed and dried at room temperature for a period of 3 days and afterwards grounded into powder. The powdered seeds were sieved and stored properly. The aqueous extract of C.albidum seeds kernel was prepared by mixing $50 \mathrm{~g}$ of the powder in $250 \mathrm{~g}$ of distilled water and then stored for 24 hours $^{13}$.

\section{Qualitative Phytochemical Screening}

\section{Ferric chloride test for Tannins}

Aportion of the sample (3g) was boiled in $50 \mathrm{~cm}^{3}$ of distilled water for 3 minutes on the heating mantle. The mixture is filtered and the resulting filtrate was used to carry out test for tannins below.

A portion of the liquid extract above was diluted with distilled water in a ratio of 1:4 and a few 2 drops of $10 \%$ ferric chloride were added. A blue or green colour indicates the presence of $\operatorname{tannin}^{14}$.

\section{Test for Saponins (Froth test)}

To a small portion of powdered sample $95 \%$ ethanol was added and boiled. The mixture was filtered and $2.5 \mathrm{~cm}^{3}$ of the filtrate was added to $10 \mathrm{~cm}^{3}$ of distilled water in a test tube. The test tube was stopped and shaken vigorously for about 30 second; it was allowed to stand for over 30 minutes. Honey-comb froth is indicative of the presence of saponin $^{2}$.

\section{Test for Flavonoids}

A quantity $(5 \mathrm{~g})$ of the powdered sample was completely dissolved in acetone. The residue is extracted in warm water after evaporating the acetone on a water bath. The mixture was filtered and the filtrate is used for the following test.

\section{Sodium hydroxide test for Flavonoids}

To $\left(5 \mathrm{~cm}^{3}\right)$ of $10 \%$ sodium hydroxide equal volume of the detanned water extracts of C.albidum was added. A yellow solution indicates the presence of flavonoids ${ }^{2}$.

\section{Ferric chloride test for Flavonoids}

A portion $\left(2 \mathrm{~cm}^{3}\right)$ of extract was diluted with distilled water in a ratio of 1:4 and a few 3 
drops of $10 \%$ ferric chloride $\left(\mathrm{FeCl}_{3}\right)$ solution is added. A green or blue solution indicates the presence of flavonoids ${ }^{2}$.

\section{Test for Alkaloids}

An extract of the powdered sample was prepared by macerating $3 g$ of the powdered sample in $50 \mathrm{~cm}^{3}$ of methanol. The extract was evaporated to dryness, $0.5 \mathrm{~g}$ of the extract was mixed with $5 \mathrm{~cm}^{3}$ of $1 \%$ aqueous hydrochloric acid and $1 \mathrm{~cm}^{3}$ of the filtrate is treated with a few drops of Hagar's reagent. Turbidity or precipitation with the reagent is taken as evidence for the presence of alkaloids in the extract ${ }^{15}$.

\section{Test for Terpenes}

The plant extract was dissolved in $2 \mathrm{~cm}^{3}$ chloroform, $1 \mathrm{~cm}^{3}$ each of acetic anhydride and concentrated $\mathrm{H}_{2} \mathrm{SO}_{4}$ were added by the side of the test tube. A reddish-violet colour indicates the presence of terpenes ${ }^{2}$.

\section{Test for Anthraquinones}

A portion of the powdered sample $(0.5 \mathrm{~g})$ was taken in test tube and $10 \mathrm{~cm}^{3}$ of chloroform was added and shaken for 5 minutes. The extract was filtered and equal volume of ammonia was added and shaken. A bright pink colour in the upper aqueous layer indicates the presence of anthraquinones ${ }^{14}$.

\section{Test for Steroids}

Concentrated $\mathrm{H}_{2} \mathrm{SO}_{4}\left(1 \mathrm{~cm}^{3}\right)$ was added to $1 \mathrm{~cm}^{3}$ of test extract. A red colour indicates the presence of steroidal ring ${ }^{17}$.

\section{Test for cardiac glycosides}

$2.0 \mathrm{~cm}^{3}$ of the ethanol extract was taken into a test tube and evaporated to dryness. The residue was dissolved in acetic anhydride and chloroform was then added. By means of a pipette concentrated sulphuric acid was added by the side of the tube. A brownish ring at the interface of the two liquids and the appearance of violet colour in the supernatant layer would indicate the presence of cardiac glycosides as reported by ${ }^{2}$.

Phytochemical Quantification Analysis (El-Olemy et al., 1994)

\section{Determination of Alkaloids}

To a $10 \mathrm{ml}$ extract of C.albidum kernel in $250 \mathrm{ml}$ separatory funnel followed by $5 \mathrm{ml}$ dil. $\mathrm{H}_{2} \mathrm{SO}_{4}$ and $5 \mathrm{ml}$ of distilled water were added. The extract was shaken twice with $10 \mathrm{ml} \mathrm{CHCl}_{3}$ and the combined $\mathrm{CHCl}_{3}$ extract was transferred to a second separating funnel containing $5 \mathrm{ml}$ dilute $\mathrm{H}_{2} \mathrm{SO}_{4}$ and
$10 \mathrm{ml}$ of distilled water. The $\mathrm{CHCl}_{3}$ layer was discarded and the aqueous acidic layer was transferred to the contents of the first separating funnel. The extract was made alkaline with ammonia and shaken for about half a minute.

The extract alkaloid was extracted completely by successive portion of $\mathrm{CHCl}_{3}$ each of $20 \mathrm{ml}$. (complete extraction was tested using Mayer's reagent). The combined $\mathrm{CHCl}_{3}$ extract was shaken with $5 \mathrm{ml}$ distilled water. The extract was run through a plug of cotton wool previously muster with $\mathrm{CHCl}_{3}$ and covered with a little anhydrous sodium sulphate, the sodium sulphate was washed with $5 \mathrm{ml}$ of $\mathrm{CHCl}_{3}$. The combined $\mathrm{CHCl}_{3}$ extract was received into a $250 \mathrm{ml}$ dry conical flask.

The $\mathrm{CHCl}_{3}$ was completely distilled and $5 \mathrm{ml}$ neutral alcohol was added and evaporated on a boiling water bath. The residue was further heated on the boiling water bath for about $10-15$ minute (to remove volatile bases). The residue was dissolved in $2 \mathrm{ml}$ of $\mathrm{CHCl}_{3}$, and $20 \mathrm{ml}$ of $\mathrm{N} / 50 \mathrm{H}_{2} \mathrm{SO}_{4}$ was added and warmed on a water bath to remove the $\mathrm{CHCl}_{3}$ completely and cooled. The excess and was titrated with $\mathrm{N} / 50 \mathrm{NaOH}$ using methyl red as indicator till the first drop of $\mathrm{N} / 50 \mathrm{NaOH}$ caused color change from pink to yellow.

\section{Calculation}

$1 \mathrm{ml}$ of $\mathrm{N} / 50 \mathrm{NaOH} \equiv 0.005787 \mathrm{~g}$ alkaloids

$\%$ Alkaloids content $=\left[20 \mathrm{ml}\right.$ taken of $\left.\mathrm{N} / 50 \mathrm{H}_{2} \mathrm{SO}_{4}\right] \times 0.005787 \times 100$

$\%=\mathrm{Z} \% \mathrm{~W} / \mathrm{V}$

\section{Determination of Flavonoids}

A $5 \mathrm{ml}$ extract was transferred to a small flask and then hydrolysed by heating on a water bath with $10 \mathrm{ml}$ of $10 \% \mathrm{H}_{2} \mathrm{SO}_{4}$ for 30 minutes. The original volume was reduced to half and the mixture was cooled on ice for 15 minutes where the flavonoids are pre-evaporated.

The cooled solution was filtered; the residue was dissolved by pouring $50 \mathrm{ml}$ of warm $95 \%$ ethanol and further made to $100 \mathrm{ml}$ with $95 \%$ ethanol. A $5 \mathrm{ml}$ aliquot was pipetted into a $25 \mathrm{ml}$ volumetric flask and diluted to volume with $50 \%$ ethanol. The absorbance of the resulting solution was measured at $370 \mathrm{~nm}$ against $50 \%$ ethanol blank. Flavonoid concentration was calculated using a reference curve of pure quercetin.

\section{Determination of Tannins}

$5 \mathrm{ml}$ of plant extract was transferred to a stoppered conical flask and $25 \mathrm{ml}$ of $0.1 \mathrm{~N}$ iodine 


\section{RESULTSAND DISCUSSION}

The present study carried out on the seed kernel revealed the presence of medicinally active constituents.

The phytochemical screening and quantitative estimation of the crude yields of chemical constituents of the plant part studied were rich in alkaloids, flavonoids, tannins, cardiac glycosides and saponins. They were known to show medicinal activity as well as exhibiting physiological activity.

The presence of alkaloids in seed cotyledon has also been reported by other researchers and this plant has anti-inflammatory effect which helps control all indications of gastritis, esophagitis, enteritis and irritating bowel disorders. Seed cotyledon contains high alkaloids and tannins and this confirm with the reportof ${ }^{19,20}$. The latter also observed that some of the sapotaceae species including Chrysophyllumdelevoyi are used for treating fibroid when grind, mix with water and potach or alcohol and potach. They are also used in the treatment of gonorrhea and hay fever. The seed cotyledons possess very high levels of alkaloids and tannins and the latter show anti-allergic, antiinflammatory, anti-microbial and anti-cancer activity.

The seed cotyledon phyto-constituents were dominated by alkaloids and tannins $(3.56 \mathrm{~g} /$ $100 \mathrm{~g}$ and $2.184 \mathrm{~g} / 100 \mathrm{~g}$ ) respectively, and that of the cardiac glycoside is $1.88 \mathrm{~g} / 100 \mathrm{~g}$ then followed by those of saponins and flavonoids $(0.24 \mathrm{~g} / 100 \mathrm{~g}$ and $0.15 \mathrm{~g} / 100 \mathrm{~g}$ ) respectively. The high tannin content of this plant may be responsible for the ethno-medicinal usage. The alkaloids may be toxic chemical element in the seed cotyledon, used as a remedy for fever. This confirms the efficacy seed against vaginal infection. This further explains the therapeutic and medicinal properties of Chrysophyllumalbidum and supported the used of this plant as an external application for skin eruptions diseases. It has been observed that tannins are responsible for anti-diarrheal activity and saponins used as dietary supplements expectorant and anti-inflammatory agent. Evaluation of the potentials of Chrysophyllumalbidum in wound care showed that the cotyledon extract exhibited haemostatic, antimicrobial and wound healing activities. The cotyledon extract mixed with shear butter oil arrested bleeding from fresh wounds by reducing bleeding and clotting time. The haemostatic effects of the extract may be due to increase in the coagulation process with the consequent reduction in clotting time as well as vasoconstriction which are necessary in limiting blood loss from damaged vessels. The phytochemicals may contribute to the wound healing activity by suppressing inflammatory reaction involved by injured tissues.

The value of alkaloids was very high in the seed cotyledon $3.56 \mathrm{~g} / 100 \mathrm{~g}$. Alkaloids are potent water soluble super antioxidant and free radical scavengers which prevent oxidative cell damage, have stronger anticancer activity and inhibit tumour growth. A study has shown that alkaloids can inhibit the development of fluids that result in diarrhea by targeting the intestinal tracts lower the risk of heart disease. The biological functions of alkaloids include protection against allergies, inflammatory, free radical scavenging, platelet aggregation, microbes, ulcers, hepatoxins, viruses and tumours. This account for the natural antioxidants by acting against oxidative stress related disease such infections as; diabetic, cancer, coronary heart diseases. Hence, people that are prone to such infections can feed on Chrysophyllumalbidum fruit as source of natural antioxidants.

\section{CONCLUSION}

The result of this study indicate that the extracts of the seeds of Chrysophyllumalbidum have good potentials as anti-inflammatory, anticancer, anti-diarrheal and anti-hemorroidal compound and further provide a rationale for the use of the seed extracts of this plant in traditional medicine.

The plant part studied here has also been as a potential source of useful drugs. Further studies are going on these plants in order to isolate, identify, characterize and elucidate the structure of the bioactive compounds.

\section{ACKNOWLEDGEMENT}

The authors are grateful to Department of Biochemistry Bayero University Kano Nigeria, 
for providing necessary chemicals and equipment's for the completion of the work.

\section{REFERENCES}

1. Aliyu, B.S. Common ethnomedicinal plants of the samarids region of West Africa their description and phytochemicals. Trumph Publishing Company limited Kano Nigeria. 2006; Pp: 180-181.

2. Sofowara, A. Medicinal plants and medicine in Afric john willeySpectrum, Ibadan.Nigeria, 1993; Pp.2, 81-85.

3. Dalziel,J.M. The useful plant of work tropical Africa.Crown Agent for the colonies. 1937; London. Pp: 524.

4. Amusa, N.A., Ashaye, O.A and Oladapo, M.O., Biodeterioration of African star apple (Chrysophyllumalbidum) in storage and the Effect on its food value.Afr. J Biotechnol. 2003; 2:56-59.

5. Okafor, J.C., The place of wild (uncultivated) fruits and vegetables in the Nigerian diet. Proceedings, Recommendations and papers of the first National seminar on fruits and vegetables. Ibadan Nigeria, 1975; Pp: 153-1154.

6. Pearson, D. Chemical analysis of foods. Churchill livingstone, London. 1976; Pp: 181.

7. Nwadinigwe, C.A., Nutritional value and mineral contents of Chrysophyllumalbidum fruit.J.SCI. Food APIC. 1952. 33, 283-28G.

8. Adisa,S.A., Vitamin C, protein and mineral content of African starapple (Chrysophyllumalbidum) in preceedings of the $18^{\text {th }}$ Annual conference of NIST. (eds). 2000; Pp: 141-146.

9. Adewusi,H.A., The African star apple Chrysophyllumalbidum indigenous knowledge from Ibadan, south western Nigeria in preceeding of a National workshop on the potentials of theStar apple in Nigeria (eds). 1997; Pp: 25-33.

10. Burits, M and Bucar, F. Antioxidant activity of
Chrysophyllumalbidum essential oil. Phtother Res 14:323-328. Institute of pharmacognosy 2002.

11. Halliwell, B., Free radicals and antioxidant: a personal view. Nutr., 1994; 52: 253-265.

12. Parasakthy, N., Boey, C., Goh K.L., An endoscopic evaluation of recurrent abdominal pain in malaysia. Malaysian journal of child health. 1996; 8: 23-27.s

13. Adeyinka A, Liang, $\mathrm{H}$ and Tina, G. Removal of metal ion from waste Water with Natural waste, School of Engineering and Technology, 2007; 33: 1-8.

14. Trease, G.E and Evans, W.C.Treaseand Evans. Pharmacognosy, $13^{\text {th }}$ edition. BelliereTindall. London, 1989; Pp: 386.

15. Sofowara, A. Medicinal plants and medicine in afric john willey spectrum, Ibadan. Nigeria, 1982; Pp.2, 101-107.

16. Adisa,S.A., Vitamin C, protein and mineral content of African starapple (Chrysophyllumalbidum) in preceedings of the $18^{\text {th }}$ Annual conference of NIST. 2000; (eds). Pp: 141-146.

17. Hassan, M.M; Oyewale, Amupitan A.O. Abdullahi, I.O. Abdullahi, M.S. and Okwonwo, E.M. Preliminary phytochemical and antibacterial investigation of the root bark of Detariummicrocarpum, J. Chem, Soc. Nigeria, 2005; 29(1): 26-29.

18. El-Olemy, M.M., F.J. Al-muhtadi and A.A. Afifi, Experimental Phytochemistry. A laboratory manual. King saud University Press, Saudi Arabia, 1994; Pp: 3-19.

19. Idowu, O., Iwalewa, E.O., Aderogba, M.A., Akinpelu B.A. and OgundamiA.O. Antinociceptive, anti-inflammatory And antioxidant activities of Eleagnine: An alkaloid isolated From Chrysophyllumalbidum seed cotyledons. Journal of Biological Sciences, 2006; 6(6,), Pp: 1029-1034.

20. Faleyimu, O.I. and Oluwalana, S.A. Medicinal value of foresplantseeds.Ogun state, Nigeria., 2008; Pp: 276. 